\title{
Tuomas Juntunen
}

\section{Tylyjen rivien rehevät välit Juha Seppälän "Taivaanranta" -novellin tyylistä}

Artikkelini tavoitteena on kokeilla perinteistä moniulotteisempaa tapaa tarkastella kaunokirjallisen teoksen tyyliä ja avata samalla intertekstuaalisia suhteita korostava näkökulma usein realistina tai naturalistina luetun Juha Seppälän proosatuotantoon. Seppälän traditiotietoisuus on toki tunnettu asia (ks. Tarkka 2000, 173), ja hänen teoksiaan on tarkasteltu intertekstuaalisesta näkökulmasta myös kahdessa tuoreessa tutkimuksessa (Kirstinä 2007; Miettinen 2008). Niissä Seppälää luetaan kuitenkin ennen muuta suhteessa kansalliskirjallisuuden traditioon, pikemminkin tiettyä tematiikkaa kuin tekstienvälisten suhteiden kokonaisuutta painottaen. Minun luennassani Taivaanranta -novellikokoelman (1987) niminovelli paljastuu suurelta osin aiempien tekstien yksityiskohdista rakennetuksi.

Lasse Koskela (1987) esittää tyypillisen mutta osuvan arvion Taivaanrannan tyylistä nimittämällä sitä tylyksi. Jos tätä varsinkin Seppälän alkutuotannolle luonteenomaista tylyyttä analysoidaan tarkemmin, sen ilmeisimmiksi osatekijöiksi voitaneen katsoa sekä muodon suppeus, tapahtumien niukkuus, kertojan pidättyvyys, virkerakenteiden yksinkertaisuus että henkilöhahmojen repliikkien lakonisuus. Seppälän 1980-luvulla kirjoittamien teosten onkin realistisuutensa ohella nähty jatkavan suomalaisen 1950lukulaisen modernismin perinnettä, jota Anna Makkosen mukaan on tapana luonnehtia adjektiiveilla "asiallinen, niukka ja objektiivinen" (1992, 94).

Lyhytproosakokoelma Super Market (1991) merkitsi Seppälän tuotannossa postmodernistista irtiottoa aiempien teosten realistis-modernistisesta tyylistä ja koko kotimaisen proosan traditiosta, joka joutui alatyylisiä aiheita ja kielenkäyttöä viljelevissä proosansirpaleissa parodian ja nurinkääntämisen kohteeksi. Sittemmin Seppälä on julkaissut molempia tyylejä edustavia teoksia; voisi puhua tuotannon modernistisesta ja postmodernistisesta haarasta. Umberto Econ mukaan tällainen modernististen ja postmodernististen piirteiden samanaikainen läsnäolo yhden ja saman kirjailijan tuotannossa on tavallista $(1992,227)$. Tunnusomaista Seppälän tuotannon tapauksessa on, että postmodernistisina luetuissa teoksissa käsitellään eksplisiittisesti samoja teemoja, joihin muussa tuotannossa vain vihjataan. Uudemmissa teoksissa kehityslinjat yhdistyvät. Kerronta on pääosin tunnistettavuuteen pyrkivää todellisuuden kuvausta, jota on tulkittu jopa naturalismin poetiikan valossa (Kantokorpi 2004). Realistisuutta kuitenkin rikkovat muun muassa kertojan metafiktiiviset väliintulot, joissa reflektoidaan tekstin rakentumista ja suhdetta todellisuuteen. 
Niukan ja vihjaavan proosakerronnan kehittäjäksi nimetään usein Ernest Hemingway. Ben Yagodan mukaan Hemingwayn lakoniseen tyyliin kuuluu - paitsi adjektiivien, kielikuvien, pilkkujen ja asioiden suhteita selventävien sanojen karsiminen - myös tarinan kannalta olennaisten tietojen ja tunteiden mainitsematta jättäminen, jolloin "jäljelle jävät sanat latautuvat erityisellä energialla” (2004, 57). Myös ”Taivaanranta” on monipuolisesta vähäeleisyydestään huolimatta täynnä merkityspotentiaalia. Tarkkaavainen luenta paljastaa ironisen tarinan pinnan alta salattuja tekoja ja niiden synnyttämiä tunteita, joista kertoja joko ei ole tietoinen tai joita hän ei ainakaan lausu julki.

Artikkelissani esitän tulkinnan "Taivaanrannasta" ja pohdin, miten novellin tyyli syntyy tekstuaalisten strategioiden ja tematiikan erottamattomuudesta. Tarkoitukseni ei ole tyytyä yksinomaan kielellisen tason tyylillisiin piirteisiin vaan tarkastella novellin tyyliä kokonaisvaltaisena ilmiönä, kaikkien sen merkityksenantokeinojen yhteistuloksena. Kielellisen tyylin asemesta tutkin novellin merkityksenannon tyyliä. Lähtökohtanani on jo René Wellekin ja Austin Warrenin esittämä näkemys, jonka mukaan tyylintutkimus on palkitsevimmillaan, kun se kykenee paljastamaan jonkin yhtenäisen, teoskokonaisuutta jäsentävän periaatteen $(1968,182)$. Tapaani lähestyä ”Taivaanrannan" tyyliä voi Antoine Compagnonin sanoin nimittää "syvempien merkitysten stilistiikaksi”. Tyyli on näin ymmärrettynä monimuotoinen ilmiö, jonka piiriin mahtuu eritasoisia osatekijöitä kielen pienimmistä yksiköistä laajoihin kulttuurisiin ja filosofisiin ongelmiin. Avarimmillaan tyyliä voidaankin tarkastella kokonaisen maailmankatsomuksen ilmaisuna. (Compagnon 2004, 124-129; Wellek \& Warren 1968, 182.)

Näkökulmani voisi ajatella edustavan muodon ja sisällön yhteenkuuluvuutta painottavaa monistista tyylintutkimusta (Leech \& Short 1981, 15). Olen kuitenkin sitä mieltä, että kielenkäytön eri funktiot huomioon ottava pluralistinen tyylikäsitys (mt., 29-34) on hedelmällisin tapa lähestyä kaunokirjallisen tekstin tyyliä. ”Taivaanrannan” tapauksessa nämä funktiot vain nähdäkseni pyrkivät yhteiseen päämäärään. Novellia hallitsevaksi tyylilliseksi periaatteeksi osoittautuu metonyymisyys, joka ilmenee yksityiskohtien avulla luotuna realismina (ks. Jakobson 1987, 111), intratekstuaalisina, läheisyyden periaatteelle rakentuvina vertauskuvien ketjuina sekä intertekstuaalisuutena, jossa toisista teksteistä lainatut yksityiskohdat kiinnittävät huomion tekstien temaattisiin kytkentöihin ja laajentavat novellin merkitysavaruutta (vrt. Haapala 2003, 153-154).

Tarkastelenkin erityisesti intertekstuaalisuutta "Taivaanrannan” tyylikeinona. Allusiivisuus on novellin keskeinen merkityksenmuodostuksen strategia, joka tukee ja täydentää sen ilmeisempiä tyylillisiä piirteitä, joita aluksi analysoin lyhyesti. Osoitan ”Taivaanrannan" kytkökset realistisen, modernistisen ja postmodernistisen kirjallisuuden laajempiin tyylillisiin virtauksiin, joiden tyypillisiä teemoja ja tekstuaalisia strategioita se yhdistelee leikkisästi mutta vakavin tarkoitusperin. Lopuksi pohdin, miten aukkoi- 
nen ja arvoituksia sisältävä, mutta vahvasti arkitodellisuuteen kytkeytyvä teos kuvastaa todellisuuden monitulkintaisuutta ja avoimuutta.

\section{Lakoninen kerronta "mielen tyylinä"}

Kertomuksen alussa keski-ikäinen taidemaalari Boman on matkalla maaseudulle tapaamaan vanhaa opiskelutoveriaan, biologianopettaja Matti Mutasta, joka etsii itselleen taloa ja on pyytänyt Bomania auttamaan etsinnöissä. Mutanen on eronnut edellisenä keväänä, entinen asunto ja lapset ovat jääneet vaimolle, ja hän elää yksin kesämökillään meren rannalla. Novelli kuvaa viikon mittaisen ajanjakson, jonka kuluessa miehet käyvät tutustumassa myytävänä oleviin taloihin, viettävät aikaa mökillä ja käyvät tanssiravintolassa, josta Boman hankkii itselleen naisseuraa. Sopivaa taloa ei viikon aikana kuitenkaan löydy, ja Boman palaa Helsinkiin. Kotiin päästyään hän saa kuulla, että Mutanen on löydetty hukkuneena. Poliisi toivoo Bomanilta tietoja, jotka voisivat olla avuksi tutkimuksissa. Boman istahtaa paperin ääreen miettimään, mitä tietää, ja tarina päättyy.

Novellin päättävä kohtaus on tekstin rakentumista peilaava upotus (ks. Dällenbach 1989, 75) ja samalla lukijalle esitetty haaste tulkita viikon tapahtumia yhdessä Bomanin kanssa. Boman miettii, että "hänen olisi kyettävä näkemään ne asiat joilla oli merkitystä niiltä joilla ei sitä ollut" ( $T R, 121)$. Näin upotus vihjaa, että Bomanin muistiinpanojen tavoin myös kaikilla niillä asioilla, jotka itse novelliin ovat päätyneet, on merkitystä loppuratkaisua tulkittaessa. Novelli tarjoaa näin lukijalle niin kutsuttua modernistista lukutapaa, jonka mukaan teksti on läpikotaisin merkityksellinen (ks. Kovala 2004, 80). Postmodernistisesta näkökulmasta vihjeen voisi tulkita myös ironiseksi, merkityksiä etsivän lukijan odotuksia kyseenalaistavaksi. Yhtä ainoaa oikeaa vastausta salaisuuksiinsa novelli ei tarjoakaan, mutta tekstin yksityiskohdille voi silti antaa merkityksiä, joiden ansiosta tapahtumien kulkua on mahdollista yrittää hahmottaa.

Ensimmäiset johtolangat löytyvät melko vähällä vaivalla. Monet seikat viittaavat siihen, että Mutanen on hukuttautunut tahallaan. Hän ottaa eräänä iltana itsemurhan puheeksi ja tunnustaa epäsuorasti harkinneensa sitä. Ennen Bomanin poislähtöä hän katselee itseään peilistä ja miettii, että hänen silmistään "olisi kenenkään vaikea sanoa tai päätellä mitään" (TR,116). Lukijalle ei paljasteta, mitä silmistä voisi olla pääteltävissä, mutta loppuratkaisun valossa näyttää luultavalta, että Mutanen on jo tässä vaiheessa tehnyt päätöksen kuolemastaan. Lisäksi novellissa mainitaan poronsarviin ripustetut pelastusliivit, joita Boman ensimmäisen kerran mökkiin astuessaan säikähtää. Tunnettua sääntöä mukaillen voidaan todeta, että jos novellissa kuvataan seinällä roikkuvat pelastusliivit, niitä on myös käytettävä. Mutanen ei kuitenkaan tee näin, ja siitä voi päätellä, että hän vähintäänkin etsii kuolemaa lähtiessään huteralla veneellä tuuliselle merelle ellei suorastaan hukuttaudu tahallaan. 
Tarkastelen aluksi novellin tyyliä termin suppeassa merkityksessä, kielellisten valintojen näkökulmasta. Tätä varten analysoin novellin alkukohtauksen kielellisiä ja kerronnallisia keinoja johdatuksena "syvempien merkitysten" analyysiin. Kuvauksessa risteää kaksi aikatasoa. Tarinan "nykyhetkessä” Boman lähestyy määränpäätään ja havainnoi tuttua ympäristöä, joka herättää hänessä muistoja edellisestä vierailusta paikkakunnalla. Imperfektissä kulkeva matkatarina vuorottelee pluskvamperfektissa kerrottujen muistojen kanssa. Samalla maisema hahmottuu kahdesta eri näkökulmasta: autoa ajava Boman tarkkailee maisemaa hallitsevia vesitornia ja tehtaan piippua alhaaltapäin, kun takautumassa puolestaan ollaan vesitornin huipulla, josta merimaisema levittäytyy Bomanin ja lukijan nähtäväksi.

Kerrontaa luonnehtii modernille proosalle tyypillinen kertojan huomaamattomuus (ks. esim. Niemi 1994, 64-65): kaikki ne ympäristöä, henkilöitä ja heidän välisiään suhteita koskevat tiedot, jotka lukijalle kuvauksessa annetaan, ovat Bomanin fokalisoimia. Mutanen ja hänen vaimonsa esitellään ohimennen, heidät jo valmiiksi hyvin tuntevan Bomanin lähtökohdista. Bomania itseään ei kuvata mitenkään; lukija vain asetetaan hänen nahkoihinsa, näkemään ja muistelemaan yhdessä hänen kanssaan, ja vähitellen hän alkaa hahmottua henkilönä. Henkilöfokalisaatiota novellissa palvelee persoonapronominien "hän" ja "se" huomaamaton vaihtelu, joka paljastaa kulloisenkin näkökulmahenkilön. Fokalisoijasta, joka alkukohtauksessa siis on Boman, kertoja käyttää "hän”-pronominia. Mutasesta puolestaan käytetään puhekielistä pronominia ”se", mikä paljastaa, että kertojanääni värittyy Bomanin ilmaisuista. Novellin kieltä ja kerrontaa analysoitaessa voikin turvautua mind stylen käsitteeseen (ks. Leech \& Short 1981, 187-207) ja tarkastella, miten kerronnassa ilmenee henkilöhahmojen tapa kokea ja tulkita maailmaansa. Vaikka alkukohtauksen fokalisoijana on Boman, tuntuu kuitenkin siltä, että novellin lakoninen tyyli ilmentää ennen kaikkea Mutasen "mielen tyyliä”, hänen elämään kyllästynyttä mielentilaansa ja tuppisuista olemustaan. Novelli on kerrottu pääosin Bomanin näkökulmasta, mutta Mutanen on sen todellinen päähenkilö. Hänen viimeisten päiviensä ajatukset ja tunnelmat Bomanin ja lukijan on määrä selvittää.

\section{Kapulakieltä ja kuvailmaisuja}

Novellin ensimmäisessä kappaleessa on tyylillisesti tarkoituksellisen kömpelöitä ilmauksia, jotka voi tulkita Mutasen puhelimessa lausumiksi sanoiksi:

Boman odotti koska tahansa suuriruhoisen sarvipään hyppäävän tielle ja puolen tonnin painollaan murskaavan hänen autonsa muodottomaksi läjäksi peltiä ja lasinsirpaleita. Hän muisti sataman suuntaan johtavan pikatien pätkän olevan siinä katsannossa maan synkintä aluetta. Missään muualla ei ollut yhtä paljon hirvikolareita suhteessa yhteen tiellä liikennöivään autoon. Mutanen oli vielä puhelimessa erityisesti varoittanut niistä. $(T R, 7$. 
Viranomaisdiskurssia parodioivat ilmaukset "siinä katsannossa" ja "suhteessa yhteen tiellä liikennöivään autoon" kiinnittävät heti aluksi huomiota kerronnan ironiseen moniäänisyyteen ja herkistävät lukijan kuuntelemaan huolella yksittäisiä sanavalintoja. Kömpelöistä muotoiluista kuvastuu myös kertojan taipumus kiinnittää kohtuuttomasti huomiota tilallisiin ja käsitteellisiin suhteisiin, jonka voi tulkita ilmentävän luonnontieteilijä Mutasen tapaa jäsentää todellisuutta.

Myös novellin kuvallisuus kytkeytyy ennen muuta Mutasen henkilöhahmoon. Alkukohtauksen niukkaa kerrontaa värittää kaksi kuvallista ilmausta. Kertoja intoutuu kuvailemaan vesitornia ja purjelautoja luonnosta valituin vertauskuvin: " $[\mathrm{t}]$ orni seisoi matalan männikön keskellä jättiläismäisen, harmaan sienen kaltaisena”, ja ”[p]urjeet olivat kaukaa tornista katsottuna näyttäneet meressä räpiköiviltä suurilta perhosilta, joiden toinen siipi oli jo vajonnut veden alle" $(T R, 8)$. Seppälälle on tyypillistä vertauskuvallisten yksityiskohtien kohostaminen kuvailmauksen avulla. Tornin merkittävyyttä lisää sen sisältämä viittaus Seppälän esikoisteokseen, jonka ”Torni”-novellin avulla voisi pohtia Bomanin näkemän vesitornin symbolisuutta. ${ }^{1}$ Perhosvertauksen mieli sen sijaan selviää helposti "Taivaanrannan” tekstinsisäisessä kontekstissa. Mutanen harrastaa perhosten keräilyä, joten Bomanin kuvittelemat metaforiset, hukkumaisillaan olevat perhoset viittaavat metonyymisesti Mutaseen ja ennakoivat hänen kuolemaansa. Hukkumiskuoleman metonyymisiä enteitä on novellissa kokonainen sarja: seinällä roikkuvat pelastusliivit, Mutasen rikkinäinen vene, verannalla lojuva murtunut snorkkeli, keskustelu kaksikymmentäluvulla uponneesta torpedoveneestä ja hukkumiskuoleman väitetystä helppoudesta, nukkuvan Mutasen hengitys, josta syntyy "samanlainen ääni kuin rantapalloa tai uimarengasta puhallettaessa" $(T R, 82)$ sekä maininta Kaarlo Sarkian runosta "Unen kaivo" (1936), jossa runon puhujan elämänvierautta verrataan veden pohjaan vajoamiseen (Sarkia 1994: 245-247).

Toinen metonyyminen viittausten sarja saa alkunsa heti novellin ensimmäisellä rivillä, kun Boman pelkää "suuriruhoisen sarvipään hyppäävän tielle". Sarvipää täsmentyy pian hirveksi, mutta alkuperäinen sanavalinta sisältää miltei huomaamattoman viittauksen myös paholaiseen. Viittaus voimistuu hiukan, kun Boman hetkeä myöhemmin katselee autonsa nostattamaa pölypilveä ja miettii, että "[s]iinä olisi pirua nyt pyörämiehellä” $(T R, 10)$. Nukkumasta yllätetty Mutanen säikähtää herätessään ja huudahtaa: "Herra Jumala". ”Ei, Boman”, Boman vastaa. (TR, 14.) Puujalkavitsinsä ansiosta hän kuitenkin vertautuu juuri Jumalaan, ja kun Mutanen myöhemmin tulen loimussa kohentelee takkaa hiilihangolla $(T R, 57)$, häneen liittyy paholaissymboliikkaa, joka vielä vahvistuu myöhemmin hänen näyttäessään tulta vasten suurelta, mustalta ja uhkaavalta $(T R, 81){ }^{2}$

Lähes kaikki novellissa kuvatut henkilöt, esineet ja ilmiöt ovat realistisen todellisuudenkuvauksen rakennuspalikoiden lisäksi metonyymisten merkitysketjujen lenkkejä, 
joissa monitasoiset tekstinsisäiset ja -ulkoiset viittaussuhteet yhdistyvät symbolimerkityksiin ja muihin kuvallisuuden muotoihin. Kielellisten merkkien merkityksen ylimääräytyneisyys tekee tekstistä monitulkintaisen pintatason niukkuudesta huolimatta.

\section{Tyyli ja intertekstuaalisuus}

Vaikka lukija päätyisikin tulkitsemaan Mutasen kuoleman itsemurhaksi, hänen salapoliisintyönsä on tässä vaiheessa vasta alussa. Monista pienistä vihjeistä on jo aiemmin voinut päätellä, että tarinaan kätkeytyy toinenkin salaisuus, jota kertoja ei paljasta. Tähän novelliin sisältyvään informaatioaukkoon viittaa muun muassa seuraava metatekstuaalinen upotus: Mutanen katselee kiinteistönvälittäjän seinällä olevaa humoristista kuvaa, jossa” Jaska Jokunen sanoi Ressulle jotain englanniksi. Siinä oli yksi pitkä sana jota hän ei ymmärtänyt eikä siitä johtuen koko vitsin ydintä" $(T R, 34)$. Upotus vihjaa, että myös sen heijastamasta tarinasta puuttuu jotain ymmärtämisen kannalta olennaista.

Miesten välillä tuntuu olevan jännitteitä, jotka johtuvat vanhoista selvittämättömistä asioista. Mutanen pohtii itsekseen, onko talonosto ollut ainoa syy pyytää Boman vierailulle, ja Boman suhtautuu epäluuloisesti Mutasen esittämiin, hänen elämäntilannettaan koskeviin kysymyksiin. Hän tuntuu kantavan syyllisyyttä jostain menneestä rikkomuksesta ja näkee painajaista, jossa Mutanen ajaa häntä takaa puukko kädessään. Vihje siitä, mistä miesten välisessä jännitteessä voisi olla kysymys, saadaan, kun Mutanen kauan epäröityään kysyy Bomanilta tämän naissuhteista. ”Se oli juuri sitä”, Boman ajattelee $(T R, 54)$. Selvittämättömät asiat tuntuvat siis liittyvän naisiin, vaikka keskusteluyritys katkeaakin kesken eikä aiheeseen enää palata. On kuitenkin luultavaa, että kysymys on Bomanin ja Mutasen entisen vaimon Pirkon välisestä suhteesta. Mikään ei tosin viittaa siihen, että Boman olisi syyllinen Mutasten eroon. Jos jotain on tapahtunut Bomanin ja Pirkon välillä, siitä on jo vuosia aikaa.

Pirkko on itse aikanaan vihjannut tähän suuntaan kertomalla Mutaselle, että Boman on joskus salaa kosketellut hänen polveaan ravintolan pöydän alla. Pirkon paljastus nostaa novellin henkilösuhteita koskevan salaisuuden ainoan kerran lähelle pintaa. Tärkeässä kohtauksessa esiintyy merkitsevästi myös alluusio, joka vahvistaa epäilystä Pirkon ja Bomanin välisestä suhteesta. Pirkon tavoitteena on kylvää epäsopua miesten välille, mutta Mutanen kääntää tilanteen Pirkkoon kohdistuvaksi moitteeksi: ”Ja sinä annoit sen tapahtua, papin tytär" (TR, 43). Mutasen vastaukseen sisältyy alluusio Juhani Ahon romaaniin Papin tytär (1885) sekä samalla tietysti myös sen henkilöiden tarinaa jatkavaan Papin rouvaan (1891).

"Taivaanrannan" ja Ahon romaaniparin henkilöiden väliset suhteet vertautuvatkin toisiinsa monin tavoin. Ahon romaanien päähenkilö Elli on papin tytär, joka rakastuu komeaan ja maailmaa nähneeseen Olavi Kalmiin, mutta päätyy naimisiin Kalmin rahvaanomaisen, fyysisesti vastenmielisen ja henkisesti lattean opiskelutoverin, pasto- 
ri Aarnion kanssa. "Taivaanrannassa” taiteellinen ja ulospäin suuntautunut Boman ja sulkeutunut, tosikkomainen Mutanen muodostavat samankaltaisen parivaljakon kuin Kalm ja Aarnio, ja Ellin tavoin Pirkko on saanut miehekseen ystävyksistä vähemmän houkuttelevan. Ellillä ja Olavilla on lyhyt rakkaussuhde pastori Aarnion selän takana, ja "Taivaanrannan" alluusio Ahon teoksiin antaa ymmärtää, että myös Pirkolla on voinut nuorena olla suhde Bomanin kanssa.

Kun epäilys Pirkon ja Bomanin suhteesta on Aho-alluusion ansiosta herännyt, voi novellissa lisäksi nähdä vihjeitä siitä, ettei tämä suhde ole jäänyt vaille seurauksia: vaikuttaa siltä, että Boman on Mutasen vanhemman lapsen Tiinan todellinen isä. Kun Mutanen kertoo nuoremmasta lapsestaan Timosta ja sanoo tuntuvan oudolta, että hänellä on jälkeläinen, Boman vastaa sen olevan "biologinen totuus" $(T R, 113)$. On merkillepantavaa, ettei kumpikaan mainitsee Tiinaa tässä yhteydessä sanallakaan. Näin ollen hän ei ehkä kuulu tämän biologisen totuuden piiriin, vaan hänen isänsä on joku muu kuin Mutanen, siis mahdollisesti Boman. Toisessa yhteydessä, kun miehet puhuvat Tiinasta, Boman yrittää jostain syystä katsoa, onko Mutanen katkeran näköinen $(T R, 29)$. Ravintolassa humalaiselta Bomanilta lipsahtaa, että hän olisi valmis vaikka tekemään "ihmisen toisen sisän̈n". Tämän jälkeen Mutanen vaipuu "synkkään puhumattomuuteen". (TR, 97.) Nähtävästi Bomanin sanat osuvat arkaan kohtaan.

Uskottomuustulkinnan valossa jo miesten ensimmäisessä keskustelussa voi nähdä merkkejä novelliin kätkeytyvästä salaisuudesta. Dialogi havainnollistaa novellin tyylillistä vähäeleisyyttä ja vihjailevuutta:

Mutanen istahti sohvalle ja sytytti tupakan. Se nosti jalan toisen päälle.

- Tilanne on mikä on, se sanoi hiljaa.

- En minä sinua syytä, Boman sanoi.

- Mistä?

- Noin, ylipäänsä. Ei ihminen ole mikään toista tuomitsemaan.

- Pirkko minut jätti.

Boman katsoi Mutasta.

- Ymmärrän.

Hän käveli lattialla edestakaisin miettivän näköisenä.

Mutanen ojentautui karistamaan tuhkaa tupakastaan. Pitkä pylväs tipahti matolle ja Mutanen peitti sen paljaalla jalallaan. $(T R, 14$.

Pitkään erossa olleiden ystävysten kanssakäyminen alkaa töksähdellen. Lyhyet repliikit tuntuvat puhuvan toistensa ohi, minkä voi tulkita johtuvan siitä, että molemmat väistelevät sitä mistä olisi tarpeellista puhua. Bomanilta lipsahtaa heti alkuun paljastava maininta syyttämisestä tai pikemminkin syyttämättä jättämisestä, mikä tuntuu Mutasesta asiaan kuulumattomalta. Mistäpä häntä pitäisikään syyttää? Pikemminkin Bomanin repliikki tuntuisi viittaavan hänen omaan syyllisyyteensä, jota hän Mutasen edessä tuntee. Hän jatkaa paljastavaa puhettaan vetoamalla Vuorisaarnan kehotukseen jättää toiset ihmiset tuomitsematta. Tähän Mutanen vastaa hiukan epäsopivasti Pirkon 
olevan vastuussa avioerosta. Mutanen tuntuu olettavan, että Boman arvelee hänen jättäneen vaimonsa. Tätä voisi tulkita siten, että molemmat miehet tietävät, että Mutasella olisi ollutkin perusteita vaimonsa hylkäämiseen. Bomanin repliikki "ymmärrän”, joka merkitsevästi toistuu novellissa monissa eri yhteyksissä $(T R, 14,20,121)$, vihjaa niin ikään siihen, että molemmat tajuavat tilanteen salatut ja kiusalliset puolet, joita symboloi Mutasen jalallaan peittelemä savukkeentuhkapylväs.

Tulkintaa Bomanista Tiinan isänä vahvistavat alluusiot kahteen muuhunkin romaaniin, joissa kuvataan tuttavapiirissä tapahtuvaa pettämistä ja toisen miehen lasta kasvattavia miehiä. Novellin loppukohtaus on paitsi metafiktiivinen upotus myös viittaus Hannu Salaman romaaniin Minä, Olli ja Orvokki (1967). Sen viimeisellä sivulla päähenkilö, kirjailija Harri Salminen, saa tietää tuttavansa Ollin naisystävän Orvokin hukkuneen. Salminen ryhtyy miettimään, mitä tietää Orvokista, ja tähän tarina päättyy. (Salama 1986, 447.)

Samankaltaisen lopetuksen lisäksi Seppälän ja Salaman kertomuksissa on muitakin yhteisiä piirteitä. Mutasen eteisessä olevat poronsarvet $(T R, 13)$ komeilevat jo Salmisten eteisen seinällä (Salama 1986, 11). Alkovi, jossa Mutanen kuulee Bomanin huohottavan ravintolasta löytyneen naisen kanssa $(T R, 101)$, palvelee samankaltaisten tapahtumien näyttämönä Alhosen ryyppäjäisissä (Salama 1986, 99). Naisten raahaaminen ravintolasta mökille puolestaan muistuttaa Salmisen, Matsin, Ollin ja kumppaneiden "sellumista" Orvokin ja muiden "huorien" kanssa Ollin huvilalla. Varmuuden vuoksi naiset vielä oma-aloitteisesti vertautuvat Salaman naisiin allekirjoittamalla Mutasen pöydälle jättämänsä lapun nimimerkillä "elokuun orvokit" ( $T R, 104)$.

Salaman romaaniin sisältyy useitakin pettämisasetelmia, joissa Salminen on yleensä pääosassa. Hänellä on romaanin kuluessa suhde sekä Ranen että Ollin morsiamen kanssa. Kaiken lisäksi Orvokki ilmoittaa odottavansa Salmisen lasta. Juuri Orvokin, Ollin ja Salmisen väliset suhteet vertautuvat "Taivaanrannasta" esiin lukemaani kolmiodraamaan. Taiteilijat Salminen ja Boman vertautuvat toisiinsa, samoin huvilanomistajat Alhonen ja Mutanen. Bomanin unessa puukkoa heiluttava Mutanen vertautuu Olliin, jonka tuttavat tietävät herkäksi tarttumaan puukkoon.

Nimet Mutanen ja Boman tuovat puolestaan mieleen parivaljakon Muttinen ja Bongman Joel Lehtosen romaanissa Kerran kesällä (1917). Nimien samankaltaisuuden lisäksi Lehtosen romaaniin viittaa laivastovierailu, josta Mutanen lukee sanomalehdestä $(T R, 54)$. Myös Aapeli Muttinen lukee lehdestä venäläisen torpedovenelaivaston vierailusta kaupungin satamassa (Lehtonen 1994, 287). Naisille katkeroituneet huvilanomistajat Matti Mutanen ja Aapeli Muttinen muistuttavatkin toisiaan monin tavoin, mutta Mutanen vertautuu myös Lehtosen tarinassa esiintyvään Matti Muikkuseen. Muikkunen on nousukas, joka isännöi huonossa hoidossa ränsistynyttä Vaskilahden kartanoa. Kuvaus Muikkusesta (mt., 33), jonka sisään astuva taiteilija Falk yllättää keskellä päivää 
vuoteesta, rinnastuu kuvaukseen Mutasesta, jonka taiteilija Boman löytää nukkumasta sotkuisessa mökissään $(T R, 13)$. Kiinnostavaa Muikkusessa Mutasen "subhenkilönä" on se, että hän kasvattaa vieraan miehen lasta. Romaanissa on myös toinen samassa tilanteessa oleva mies, kauppaneuvos Könölin, jonka vanhemman tyttären todellinen isä on rikas liikemies Adler.

Aviorikosta käsittelevien intertekstien ohella novellilla on toinenkin laaja intertekstien ryhmä: suomalaiset sodan kuvaukset, jotka taustoittavat sekä novellin esittämää yhteiskuntakritiikkiä että maskuliinisuuden ongelmien tarkastelua. Novellissa mainitaan nimeltä Eino Hosian romaani Tuliholvin alla (1940), Olavi Paavolaisen muistelmateos Synkkä yksinpuhelu (1946), sotarunoilija Yrjö Jylhän runo ”Laulu Kuujärvestä” (1936) sekä monet sota-ajan suositut laulut. Näiden tekstien mainitseminen ei vaadi paljon sanoja, mutta niiden avulla aktivoidaan käytännössä koko suomalainen sotakirjallisuus monine äänineen ja arvoineen taustoittamaan kuvausta Bomanin ja Mutasen vierailusta sota-aluksella.

Kahta tärkeintä sotakirjallisuuden intertekstiään novelli ei kuitenkaan paljasta yhtä avoimesti. Novellissa on kohtaus, jossa Boman ja Mutanen ajavat taksilla Mutasen mökille kaksi ravintolasta löytynyttä naista mukanaan. Matkan aikana siteerataan Jylhää ja lauletaan Reino Helismaan sanoittamaa kappaletta "Täysikuu”. Intertekstuaalisen tulkintakehyksen aktivoivien sitaattien lisäksi kertoja vihjailee koko kohtauksen olevan intertekstuaalinen: Mutanen, jonka näkökulmasta kohtaus fokalisoituu, ajattelee "kokeneensa tämän kaiken jo monta kertaa" (TR, 98). Lisäksi hänestä tuntuu siltä kuin "auto olisi voinut olla matkalla mihin tahansa" $(T R, 99)$, mikä niin ikään viittaa kohtauksen ei-ainutkertaisuuteen. Se rakentuukin kokonaisuudessaan Paavo Rintalan Sissiluutnantin (1963) varaan. Rintalan romaanissa on vastaava kohtaus (mt., 126-132), jossa luutnantti Takala ja kapteeni Kokkonen ottavat huoltoportaasta kaksi lottaa mukaansa etulinjaan. Riehakas Takala istuu takapenkillä naisten välissä kädet näiden kaulalla, ja samoin tekee Boman. Paheksuva Kokkonen istuu etupenkillä kuljettajan vieressä, samoin tekee vastahakoinen ja kiusaantunut Mutanen. Perillä etulinjassa Takala "parittelee" toisen lotan kanssa saunan pukuhuoneen penkillä; "Taivaanrannassa" pukuhuoneen penkille puolestaan päätyy Mutanen, joka, ironista kyllä, joutuu jälleen kerran luovuttamaan vuoteensa Bomanin käytettäväksi ja päätyy näin symbolisesti toistamaan kokemansa nöyryytyksen sen sijaan että saisi vuosien takaiset asiat vihdoin selvitettyä.

Mutasen mökkinaapuri Eerolan nimi puolestaan viittaa samannimiseen hahmoon Väinö Linnan Tuntemattomassa sotilaassa (1954). Kuolevasta ja hourailevasta sodan uhrista on tosin Seppälän ironisessa tarinassa tullut terveyttä uhkuva, sotaa ihannoiva tervaskanto. Nimen lisäksi Linnan romaaniin viittaa eräs Eerolan suuhun laitettu lause: hän lohduttaa krapulaista Bomania, joka krapulaansa salaillakseen valehtelee vilustu- 
neensa laivastovierailun yhteydessä, sanomalla että tämän "uhri ei ollut turha" ( $T R$, 105). Sanat ovat peräisin Tuntemattoman sotilaan kertojalta, jonka mukaan talvisodan veteraanit pohtivat, "[o]liko uhrimme ollut turha" (Linna 1955, 5). Eerolan hahmon ironisuutta lisää se, että hänen ulkomuotonsa, vegetaristinen elämäntapansa ja luonnonmukaisuutta painottavat terveysteoriansa ovat peräisin toiselta Linnan henkilöhahmolta, Täällä Pohjantähden alla -trilogian (1959-1962) räätäli Halmeelta, jonka maailmankatsomus kieltää kaiken tappamisen.

Bomanin nimi viittaa Pentti Holapan samannimiseen novelliin kokoelmassa Muodonmuutoksia (1959). Holapan Boman on koira, joka oppii puhumaan ja kasvattaa lopuksi itselleen siivet voidakseen lentää. Bomanissa "kaulapannalla varustettu ja siivitetty eläin" ovat "alinomaisessa vuorovaikutuksessa" (1959, 54-55). Näin se on eksistentialistinen vertauskuva ihmisestä, jonka olemista luonnehtivat toisaalta äärimmäinen vapaus, toisaalta tietyssä situaatiossa oleminen eli ne ulkoiset ja sisäiset rajoitukset, joiden puitteissa valinnat on tehtävä.

Holapan Boman on sekä Mutasen että Bomanin kirjallinen esikuva. Nimen synnyttämää kytkentää vahvistaa Bomanin osalta kertojan huomio, että hän raatelee grillattua broileria "kuin koira" $(T R, 53)$. Toisaalta myös sateessa kastuneen Mutasen hampaat kalisevat kuin koiralla $(T R, 77)$, ja aiemmin hän on roikottanut käsivarsiaan "sivuillaan niin kuin joitain ylimääräisiä kasvannaisia” $(T R, 29)$, mikä viittaa Boman-koiran kasvattamiin siipiin.

Taru Väyrynen (2001, 186-188) tulkitsee Bomanin siipien kuvaavan yhtäältä taiteen syntyä ja toisaalta viittaavan Platonin Faidrokseen, jossa kerrotaan myytti sielun liikkeistä aineellisen todellisuuden ja ideaalisen tosiolevan välillä. Kauneuden herättämä rakkaus saa Sokrateen mukaan sielun kasvattamaan itselleen siivet, joiden avulla se voi kohota katsomaan tosiolevaista. Samalla myös rakkauden kohde saa siivet nähdessään kauneutensa heijastuvan rakastuneesta. Väyrysen mukaan Bomanin ja sen omistajan suhde muistuttaa tätä vastavuoroista siipien lahjoitusta. Bomanin siipien kasvun edellytyksenä on tosin myös ruumiillinen rakkaus: se saa siipensä vasta annettuaan periksi eläimelle itsessään ja pariteltuaan tavallisten koirien kanssa. Siivekäs Boman on siis vertauskuva ihmisestä, joka toteuttaa itseään sekä rakkauden että taiteen tai jonkin muun elämälle merkityksen antavan tehtävän avulla. Myös Seppälän henkilöt pyrkivät siivilleen, mutta kuten Mutasen roikottamat käsivarret vihjaavat, yritys ei toteudu missään niistä merkityksistä, joita siivet saavat. Taiteen, tieteen ja rakkauden siivet ovat heille vain irvikuva siitä, mitä ne voisivat olla.

"Taivaanrannan" henkilöt ja sen fiktiivinen todellisuus ovat siis läpikotaisin intertekstuaalisia, aiempien tekstien yksityiskohdista rakennettuja. Intertekstuaalisuus mahdollistaa novellin suhteuttamisen suomalaisen proosan traditioon ja sen eri tyylisuuntiin. Aho-alluusio, joka ainakin "Taivaanrannan” omalla mittapuulla mitattuna on 
varsin näkyvä, kiinnittää huomion siihen, mistä novellissa on salatusti kyse: se on tarina 1800-luvun realistiselle ja naturalistiselle kirjallisuudelle tyypillisestä, traagisiin seurauksiin johtavasta aviorikoksesta (vrt. Maijala 2008, 79). Pastori Aarnion lisäksi Mutasen hahmossa voikin nähdä muistumia myös esimerkiksi Dostojevskin Ikuisen aviomiehen (1870) Pavel Pavlovitšista, joka joutuu naisasioissa toistuvasti ystävänsä pettämäksi, tai Tolstoin Anna Kareninan (1875-77) Kareninista, tunnollisesta virkamiehestä, joka menettää vaimonsa Vronskille, komealle upseerille. ”Taivaanrannan” metonyymisessa kontekstissa on melkeinpä osoittelevaa, että Bomanin arvuutellessa Pirkon lähdön syitä Mutanen arvelee tämän ainoan tavoitteen elämässä olevan "kuolla kunniallisesti joku Tolstoi tai virkkuutyyny kourassa" $(T R, 47)$. Mutasen arvio entisestä vaimostaan ei ole järin uskottava, ja siihen sisältyvä alluusio Tolstoin kunniattomasti kuolevaan naishahmoon vihjaakin Pirkon toivoneen elämäänsä vaihtelua ja intohimoa.

"Taivaanrannan" intertekstuaalisten suhteiden avulla voi havainnollistaa tyylin normatiivista ulottuvuutta (ks. Compagnon 2004, 125), joka ilmenee novellissa ironisina viittauksina toisenlaista tyyliä edustaviin teoksiin. Esimerkkinä tästä on sisäkertomus Mutasen ja Pirkon vierailusta Kaarlo Sarkia -museossa. Sarkia teoksineen ironisoituu, kun museon ovenpielessä olevan roskaämpärin "roskia"-teksti assosioituu Mutasen mielessä Sarkiaan. Ironian voi tulkita kohdistuvan Sarkian riimeillä ja rytmeillä koreilevan ja kuolemaa romantisoivan tyylin vanhanaikaisuuteen, ja se vain voimistuu, kun museon opas saapuu humalaisena paikalle "koko Sarkian" unohtaneena. $(T R, 31$.

Toinen ironian kohteeksi joutuva kirjailija on Eino Hosia, jonka romaani Tuli holvin alla on koomisena hahmona kuvatun Eerolan suosikkiteos. Romaani kertoo talvisodasta, ja se mytologisoi suomalaisten puolustustaistelua vyöryttämällä Raamattuviittauksia, joiden ansiosta suomalaiset sotilaat vertautuvat ristiinnaulittuun Jeesukseen ja Suomen kansa Israelin valittuun kansaan, joka juuri erikoisasemansa vuoksi on velvoitettu kärsimään. Hosian kirja ja sen myötä Eerola edustavat suomalaisen soturikunnon ihannointia, jota "Taivaanranta" kritisoi. Hosia ja Sarkia ovat molemmat suomalaisen modernismin läpimurtoa edeltäneiden 1930- ja 1940-lukujen kirjailijoita, joten heidän ironisoimistaan voisi pitää osoituksena "Taivaanrannan" kiinnittymisestä viisikymmenlukulaiseen estetiikkaan. Viisikymmenlukua novellissa edustavat myös sen suhteet Holapan eksistentialistiseen "Boman”-novelliin sekä Linnan teosten realismiin.

Realismin ja modernismin ohella tässä intertekstuaalisten viittausten runsaudessa voi kuitenkin nähdä enteitä Super Marketin jälkeisen tuotannon postmodernistisista kerronnan ja merkityksenannon (tai merkityksen lykkäämisen/kyseenalaistamisen) keinoista (vrt. Karkama 1994, 303-304). Realistista "läpinäkyvyyttä" ja viisikymmenlukulaista vähäeleisyyttä kunnioittavasta pinnastaan huolimatta "Taivaanranta" on postmodernin ajan kirjallisuutta: se poimii kirjallisuuden traditiosta viittauskohteita ja leikkii niillä suvereenisti, ironisoiden mutta silti vakavin tarkoitusperin. Postmoder- 
nismi ja merkitysten problematisoituminen ei Seppälän tapauksessa tarkoitakaan nihilististä merkityksistä luopumista. Tarkastelen artikkelini lopuksi sitä, millainen käsitys merkityksellisyyden ehdoista "Taivaanrannasta" välittyy.

\section{Tyyli ja maailmankatsomus}

"Taivaanranta" on kuvaus ongelmallisista, valheellisiksi muuttuneista ihmissuhteista ja yksinäisyydestä, mutta samalla se käsittelee yleisemmin inhimillisen olemassaolon ehtoja ja elämän mielekkyyden katoamista. ${ }^{3}$ Sekä taiteilija Boman että luonnontieteilijä Mutanen ovat ammatillisessa umpikujassa. Bomanin tulokseton taiteilu on jo pitkään tuntunut itsepetokselta, ja Mutasen suuri projekti, suomalaisten perhoslajien kokoelma, on valmis. Molemmilta miehiltä on riistetty tehtävä, joka antaisi heidän olemassaololleen merkityksen, ja he reagoivat tilanteeseen itselleen luonteenomaisesti: Boman palaa kotiinsa ja jatkaa tarkoituksetonta olemistaan, Mutanen puolestaan päättää lopettaa elämänsä. Seppälän tylyä tyyliä on se, että Mutasen kuoleman vihjataan olevan suoraselkäisempi valinta kuin Bomanin jatkettu itsepetos.

Bomanin eksistentiaalista tilannetta kuvastaa kohtaus kotimatkalta: "Viimeisestä liikenneympyrästä erkani teitä moneen suuntaan. Boman piti rattia samassa asennossa ja kiersi tyhjän ympyrän kolme kertaa ennen kuin valitsi niistä yhden” $(T R, 118)$. Seuraavan luvun alussa Boman löytyy makaamassa kaupunkiasuntonsa sijaamattomalla vuoteella, joten mitään uutta ratkaisua hän ei ole kyennyt tekemään. Liikenneympyrän tyhjyys tosin antaa ymmärtää, ettei mitään mielekkäitä vaihtoehtoja olisi ollutkaan. Mutaseen verrattuna hän osoittautuu juuri sellaiseksi huijariksi, joiksi Mutasen naapuri Eerola taiteilijoita epäilee $(T R, 51)$ ja jollainen hän itsekin myöntää olevansa $(T R, 81)$.

Päähenkilöiden ratkaisuja kuvastaa kohtaus, jossa he ovat katsomassa myytävänä olevaa taloa. Myyjä, välittäjä, Boman ja Mutanen ovat kiivenneet vintille. Mutanen huomaa hämähäkinverkon, jossa kaksi vielä elävää kärpästä pörisee yrittäen päästä pakenemaan. Hän vapauttaa kärpäset, joista toinen lähteekin heti lentoon, mutta toinen juuttuu hetken käveltyään "vakaasti paikalleen" eikä suostu enää osoittamaan elonmerkkejä. (TR, 88-90.) Vapautetut kärpäset vertautuvat novellin päähenkilöihin ja symboloivat samalla yleisemmin modernistiseen "välitilaan" (ks. Karkama 1994, 209-239) joutuneita ihmisiä, joiden olemassaoloa perinteiset maailman hahmottamisen tavat eivät enää kannattele. Paikoilleen jähmettyvä kärpänen vertautuu Mutaseen, jonka ratkaisua sen käyttäytyminen ennakoi. Lentoon lähtevä kärpänen taas vertautuu Bomaniin, joka kykenee elämään vailla sitovia kahleita.

Miehet poistuvat vintiltä "täsmälleen päinvastaisessa järjestyksessä kuin olivat sinne nousseet" (TR, 90). Koska Mutanen on tapansa mukaan noussut vintille joukon viimeisenä, hän siis poistuu sieltä ensimmäisenä. Tämä vihjaa hänen tehneen ratkaisun, ottaneen vastuun omasta olemassaolostaan uudella tavalla. Hän on muuttunut "jälki- 
joukon valvoja[sta]" ( $T R, 42)$ omat valintansa tekeväksi yksilöksi, ja hänen valintansa on kuolema, joka Martin Heideggerin mukaan on yksilön (Daseinin) "[o]min, riippumaton, sivuuttamaton ja varma mahdollisuus" $(2000,324)$ ja jota kohti olemassaolon tulee suuntautua. Bomanin rinnalla Mutanen näyttäytyy autenttisena yksilönä, joka ei väistele kuolemaansa.

Eksplisiittisemmin muttei suinkaan vähemmän tylynä sama elämänkatsomus käy ilmi Tunnetteko tyypin? -kokoelman (1995) lyhytproosatekstistä "Mies palasi kaupungista kusi housussa", jossa rappioalkoholistin kuvaus päättyy seuraavaan elämänfilosofiseen julistukseen:

Väitetään, että elämä on arvo sinänsä kaikissa olosuhteissa, mutta tämän tarinan opetus on päinvastainen: tässä laahustaa kusi housussa kaupungista kotiin mies joka ei koe elämällään olevan vähintäkään merkitystä. Hänellä ei ole sen jatkamiseen halua eikä kykyä ja hänen lähiympäristönsä on asiasta täsmälleen samaa mieltä. Vielä hetken pitää kuitenkin asennoitua niin kuin asevelvollisen palveluksen viimeisinä, tarkoituksettomina päivinä: olla täytyy. (Seppälä 1995, 99-100.)

Seppälän teoksissa merkityksetön olemassaolo on arvotonta. Henkilöt kuvataan usein tilanteissa, joissa elämän tarkoituksettomuus paljastuu heille. Myönteisimmässä valossa esitetään ne henkilöt, jotka osaavat tehdä tilanteestaan oikean johtopäätöksen.

"Taivaanrannasta" voi silti löytää myös vaihtoehtoisia tapoja tulkita Mutasen ratkaisua. Kun hän kertoo Bomanille elämäntyönsä olevan tehty, Boman vastaa sen olevan mahdotonta: ”Ei Sisyfos saa kiveään koskaan vuoren laelle." Albert Camus'n tunnettua tulkintaa mukaillen Boman näkee päättymätöntä kivenvierittämisrangaistustaan manalassa kärsivässä Sisyfoksessa ihmisen vertauskuvan: "Sisyfos on ihminen yleensä. Jokainen ihminen on Sisyfos." ( $T R, 50$.) Camus'n mukaan jumalattomaan maailmaan hylätty, absurdiin vapauteensa tuomittu ihminen voi Sisyfoksen tavoin kohota kohtalonsa yläpuolelle halveksimalla sitä ja olemalla "päiviensä herra" (Camus 1962, 106). Camus'läisestä näkökulmasta Mutasen itsemurha näyttäytyisi näin pikemminkin luovuttamisena kuin autenttisena valintana. Bomankaan ei oikein tahdo yltää Camus'n Sisyfoksen ylevyyteen, mutta kiven vieriminen takaisin laaksoon antaa hänelle kuitenkin mahdollisuuden jatkaa elämäänsä.

Viitteet paholaiseen ja Jumalaan tuovat kristillisen maailmankatsomuksen osaksi novellin merkitysavaruutta. Sen mukaan itsemurha on kadotukseen johtava rikkomus Jumalan käskyjä vastaan. Kadotukseen joutumista kutsutaan Raamatussa toistuvasti hukkumiseksi, ja näin ollen Mutasen kuolintapa voitaisiin tulkita myös osoitukseksi hänen ratkaisunsa tuomittavuudesta. Tällaiset vihjeet kristilliseen tulkintaan on joka tapauksessa ymmärrettävä ironisiksi, mikäli eksistentialistisista tulkintavaihtoehdoista halutaan pitää kiinni.

Ehkä eri tulkintatapojen välillä ei tarvitse yrittääkään tehdä valintaa. Voidaan ajatel- 
la, ettei novellin tavoitteena ole arvottaa Mutasen ratkaisua vaan tarjota lukijalle joukko mahdollisia arvottamisen lähtökohtia. Lukija voi valita niistä jonkin tai päätyä hyväksymään sen, ettei ongelmaan ole oikeaa vastausta. "Taivaanrannan" moniarvoisuus toistaa maailmankuvan tasolla novellin yksityiskohtien monimerkityksisyyttä ja sen henkilöhahmojen intertekstuaalista monilähteisyyttä. Novellin arvomaailma voidaankin hyvin laskea yhdeksi sen tyylillisistä piirteistä.

\section{Tyyli ja representaatio}

”Taivaanrannan" päähenkilöiden yksilöllisillä valinnoilla on yleisempääkin merkitystä: ne kuvastavat luonnontieteen ja taiteen vastakohtaisia tapoja suhtautua todellisuuteen. Boman luonnehtii taiteilijaa traagiseksi poikkeusyksilöksi, joka on tuomittu aina näkemään heinäseipäässä muutakin kuin heiniä. Luonnontieteilijälle riittää Bomanin mukaan se, että hämähäkillä sanotaan olevan kuusi jalkaa; tiede mittaa ja luokittelee ilmiöitä, taide antaa niille merkityksiä. Vaikka Bomanin harjoittama taiteilijuuden mystifiointi onkin hiukan koomista ja ironisoitua, hänen taidekäsityksensä voi kuitenkin tulkita myös novellin sisäistekijän näkemykseksi taiteen merkityksestä.

Taiteellisen representaation kysymyksiä ilmentää novellissa Bomanin piirros tervalepästä, jossa hän näkee sanoin selittämätöntä herkkyyttä. Mutanen ei tätä herkkyyttä tavoita, mutta tarpeeksi kauan katsottuaan hän on hetken ajan näkevinään kuvassa ihmiskasvot. (TR, 110-113.) Todellisuuden taiteellinen representaatio sallii ihmisen nähdä todellisuudessa oman kuvansa, kokea maailman tuttuna ja merkityksellisenä. Todellisuus ei ole ihmistä varten tehty, asioilla ei ole merkitystä itsessään, vaan ihmisen on se niille annettava. Tätä taiteen tehtävää "Taivaanrantakin” toteuttaa, mikä selittää sen näennäisen paradoksin, että novelli kuvaa merkitysten katoamista mutta on samalla merkitystä täynnä. (Vrt. Koskela 1987.)

Nämä merkitykset eivät mahdollista yhtenäistä, koherenttia tulkintaa. Se tekstin kokonaisuutta kuvastava tyylillinen periaate, jonka selvittämisen aluksi asetin tavoitteekseni, onkin hiukan paradoksaalisesti monitulkintaisuus, jonka taustalla on modernille proosalle tyypillinen pyrkimys kuvata yksilön rajoittunutta ja epävarmaa kokemusta todellisuudesta. Tätä tavoitetta palvelee myös johdonmukainen henkilöfokalisaatio. Jo novellin nimi tuo tekstiin yksilöllisyyden tematiikan: taivaanranta, horisontti, määräytyy jokaiselle yksilöllisesti hänen kulloisenkin sijaintinsa mukaan. Lisäksi se on aina liikkeessä ja pakenee havaitsijaansa. Novellin viimeisellä sivulla on seuraava, kaiken havaitsemisen subjektiivisuutta korostava kuvaus: "Pihalta alkoi kuulua maton hakkaamisen ääni, ja kun Boman meni ikkunalle, hän huomasi lyöjän käden olevan aavistuksen verran myöhässä tai päin vastoin.” (TR, 121). Äänen ja valon nopeuden yhteismitattomuus väristää kuulo- ja näköhavainnon välisen suhteen, ja havaitsijan ongelmana on päättää, kumpaa havaintokokemuksen komponenttia hän pitää normi- 
na, kumpaa normista poikkeavana. Kohtaus kuvastaa jälleen hyvin novellin vähäeleistä tyyliä: selityksiä vaille jäävä pieni havainto laajenee lukijan mielessä kokonaisen todellisuuskäsityksen vertauskuvaksi.

Inhimillisen olemassaolon rajoittuneisuuden ohella monitulkintaisuus kuvastaa erityisesti modernin yhteiskunnan ristiriitoja. Mutanen on maalaispoika, joka on riuhtaistu juuriltaan tavoittelemaan paikkaa sivistyneistön joukossa. Hän on kuitenkin jäänyt yrityksessään puolitiehen. Boman toteaakin pilalle mennyttä elämäänsä valittavalle Mutaselle: "Tätä kaikkea kutsutaan yhteiskunnalliseksi rakennemuutokseksi. [--] Sinä et ole mukautunut muutokseen. Sinun maailmasi on jo mennyt. Sinä olet puolivälin ihminen.” $(T R, 80$.) Näin eksplikoituu se välitilassa oleminen, jota verkosta vapautetut kärpäset symboloivat. Modernin maailman ristiriitaisia vaatimuksia puolestaan symboloi Mutasen kohtaloksi koituva ristiaallokko, johon hän lähtee Eerolalta, aikansa eläneiden arvojen edustajalta, lainatulla kiikkerällä veneellä. ”Taivaanranta” kuvaa modernin subjektin pirstoutuneisuutta ja perustattomuutta ongelmallisena, jopa traagisena asiana. Suhteessaan subjektin problematiikkaan novelli - tai ainakin Mutasen henkilöhahmo - edustaa siis pikemminkin modernistista kuin vapautuneeseen identiteeteillä leikittelyyn perustuvaa postmodernistista näkökulmaa.

Tekstin monitulkintaisuutta kuvastaa myös metatekstuaalinen upotus: "Boman alkoi touhuta kahvivettä kaasuliedelle. Letku kulki lieden takaa komeroon. Boman avasi oven ja tutki lattialla olevan kaasupullon korkin symboleja. Nuolia oli siinä molempiin suuntiin.” $(T R, 15$.$) Korkin symboleja tutkivan Bomanin tavoin tekstin symboleja ja$ viittauksia tutkiva lukija saa huomata, että vihjeet osoittavat moniin mahdollisiin tulkintoihin, joista hänen on valittava. Boman voi olla Mutasen tyttären isä tai sitten ei. Mutasen kuolema voi olla itsemurha tai onnettomuus. Jos se on itsemurha, sen syynä voi olla ystävän ja vaimon yhteinen petos, mutta yhtä hyvin itsemurhayllykkeen voi laukaista avioero, elämäntyön valmistuminen tai se, että tavoiteltua taloa (ja siten vertauskuvallisesti ehjää identiteettiä) ei löydy. Tyly tyyli sysää vastuun tulkinnoista lukijalle.

\section{Lopuksi}

Tyylianalyysini teoreettisena lähtökohtana oli Antoine Compagnonin avara käsitys tyylin eri ulottuvuuksista. Olen omaksunut Compagnonilta pikemminkin yleisen asenteen tyyliä kohtaan kuin turvautunut hänen luokitteluunsa mahdollisista tyylin tarkastelemisen tavoista. Lähtökohtaani voidaan kritisoida väittämällä, että siinä tyyli merkitsee kaikkea eikä siis enää mitään. Olen pyrkinyt osoittamaan, että merkityksenannon tyyliä tutkimalla voidaan saavuttaa kiinnostavia tuloksia, vaikka tyylin käsitettä joudutaankin tällöin laajentamaan, kenties triviaalin rajoille saakka. ”Taivaanranta”, kuten Seppälän muutkin tekstit, on siinä määrin intertekstien läpäisemä, että sen tyylin tutkiminen 
intertekstuaalisuuden pois sulkevasta näkökulmasta olisi tarkoituksetonta. Suppeammin ymmärretyn tyylikäsitteen valossa "Taivaanrannan" kielellistä tyyliä voisi kutsua läpinäkyväksi: se ei pakota lukijaa kiinnittämään huomiota kieleen vaan mahdollistaa tarinan lukemisen realistisena todellisuuden kuvauksena. Vasta merkityksenannon tyyliä tutkittaessa käy ilmi tämän todellisuusilluusion läpikotaisin intertekstuaalinen rakentuminen. Yhteenvetona voidaan esittää, että "Taivaanrannan" metonyymisyyteen ja vihjaavuuteen perustuvat tyylikeinot ilmaisevat todellisuuden monitulkintaisuutta, josta seuraa mimeettisten taideteosten monitulkintaisuus.

"Taivaanranta" on tyypillistä modernia suomalaista proosaa yhdistäessään realistisia, modernistisia ja postmodernistisia tendenssejä (ks. Karkama 1994, 298-299), joiden voi yleistäen katsoa vastaavan sen yhteiskunnallisia, eksistentiaalifilosofisia ja representaation kysymyksiä käsittelevää tematiikkaa. Näihin teemoihin olen tilanpuutteen vuoksi voinut vain viitata, joten niiden perusteellisempi tarkasteleminen jää tulevan Seppälä-tutkimuksen asiaksi. Toivon osoittaneeni, että Seppälän teoksia tutkittaessa on syytä lukea tylyjen rivien lisäksi myös niiden rehevät välit, jotka rikastavat tulkintaa ja ohjaavat tulkitsijaa uusiin ja yllättäviinkin suuntiin.

\section{Viitteet}

${ }^{1}$ Yhteyttä Torni-kokoelman (1986) niminovelliin vahvistaa henkilöasetelman samankaltaisuus: Molemmissa novelleissa kuvataan kahden miehen välistä jännittynyttä yhdessäoloa. Toinen miehistä on molemmissa tapauksissa äskettäin eronnut.

${ }^{2}$ Paholaisviitteitä on monissa muissakin Seppälän teksteissä. Syksyllä 2008 ilmestynyt romaani on jopa nimeltään Paholaisen haarukka. Kirjan nimi kuvastaa artikkelin johdannossa mainitsemaani suuntausta Seppälän tuotannossa: myöhempien teosten tematiikka on eksplisiittisempää kuin aikaisempien.

${ }^{3}$ Erkki Sevänen valmistelee parhaillaan tutkimusta, jossa hän tarkastelee Seppälän teoksia kuvauksina mielekkään olemassaolon tavoittelusta.

\section{Lähteet}

$T R=$ SEPPÄLÄ, JUHA I987: Taivaanranta. Proosaa. Helsinki: WSOY.

CAMUS, Albert 1962/1942: Sisyfoksen myytti. Esseitä. Alkuteos: Le mythe de Sisyphe. Suom. Leena Löfstedt. Helsinki: Otava, 102-107.

compagnon, antoine 2004/1998: Literature, Theory, and Common Sense. Alkuteos: Le Démon de la théorie: littérature et sens commun. Trans. Carol Cosman. Princeton and Oxford: Princeton University Press.

DÄLlenbaCH, LUCIEN 1989/1977: The Mirror in the Text. Alkuteos: Le Récit spéculaire: 
essai sur la mise en abyme. Trans. Jeremy Whiteley and Emma Hughes. Cambridge: Polity Press.

eco, umberto 1992/1985: Postmodernism, Irony, the Enjoyable. Modernism/Postmodernism. Ed. Peter Brooker. Longman Critical Readers. London and New York: Longman, 225-228.

HAAPAla, veSA 2003: Kutsuja, hyppyjä, tilavaa puhetta. Pentti Saarikosken myöhäistuotannon metonyymisia ratkaisuja. Kuvien kehässä. Tutkielmia kirjallisuudesta, poetiikasta ja retoriikasta. Toim. Vesa Haapala. Tietolipas 191. Helsinki: SKS, 144-182.

HeidegGer, Martin 2000/I927: Oleminen ja aika. Alkuteos: Sein und Zeit. Suom. Reijo Kupiainen. Tampere: Vastapaino.

HOLAPPA, PENTTI I959: Muodonmuutoksia. Helsinki: WSOY.

Jakobson, Roman 1987/1956: Two Aspects of Language and Two Types of Aphasic Disturbances. Language in Literature. Ed. Krystyna Pomorska and Stephen Rudy. Cambridge, MA and London: The Belknap Press of Harvard University Press, 95-114. KANTOKORPI, MERVI 2004: Shokkihoitoa alusta alkaen. Helsingin Sanomat 18.9.2004. KARKAMA, PERTTI I994: Kirjallisuus ja nykyaika. Suomalaisen sanataiteen teemoja ja tendenssejä. Helsinki: SKS.

KIRSTINÄ, LEENA 2007: Kansallisia kertomuksia. Suomalaisuus 1990-luvun proosassa. Helsinki: SKS.

KOSKELA, LASSE I987: Tylyä tyyliä ja kohtalaista hapuilua. Parnasso 6/1987, 395-396. KOVALA, URPO 2004: Modernistinen lukutapa ja sen kritiikki. Katkos ja kytkös. Modernismin ja postmodernismin subde traditioon. Toim. Katriina Kajannes, Leena Kirstinä ja Annika Waenerberg. Helsinki: SKS, 78-95.

LEeCh, GeOfFrey \& SHORT, MiChael I98 I: Style in Fiction. A linguistic introduction to English fictional prose. English Language Series 13. London and New York: Longman. LEHTONEN, JOEL I994/I917: Kerran kesällä. Helsinki: SKS.

LINNA, VÄINÖ I955/I954: Tuntematon sotilas. Yhdeksäs painos. Helsinki: WSOY. maijala, minna 2008: Passion vallassa. Hermostunut aika Minna Canthin teoksissa. Helsinki: SKS.

MAKKONEN, ANNA I992: Kokeilijoita ja sivullisia. Näkökulmia 1950-luvun proosaan. Avoin ja suljettu. Kirjoituksia 1950-luvusta suomalaisessa kulttuurissa. Toim. Anna Makkonen. Helsinki: SKS, 93-121.

MIETTINEN, ARTO 2008: Kansallisen uudet tulkinnat. Suurten kertomusten problematisoituminen Juha Seppälän tuotannossa. Lisensiaatintutkielma. Joensuun yliopisto.

NIEMI, JUHANi I994: Modernia muotoa etsimässä. Suomalaisen proosan modernismin juurilla. Julkaisuja 34. Tampereen yliopisto, Suomen kirjallisuus.

Rintala, PaAvo I963: Sissiluutnantti. Proosaa rinta-ja kurkkuäänille. Helsinki: Otava. Salama, Hannu i986/ı967: Minä, Olli ja Orvokki. Romaanit 2. Helsinki: Otava. 
SARKIA, KAARLO I 996/1944: Runot. Kolmastoista painos. Helsinki: WSOY.

SEPpÄцÄ, JUHA I 986: Torni. Novelleja. Helsinki: WSOY.

SEPpäLÄ, JUHA I995: Tunnetteko tyypin? Tapauksia, oikkuja, sattumuksia. Helsinki: WSOY.

TARKKa, PEKKa 2000: Suomalaisia nykykirjailijoita. Kuudes laitos. Helsinki: Tammi. väyrynen, taru 200I: Pentti Holappa. Kirjailijakuva vuoteen 1961. Helsinki: Yliopistopaino.

Wellek, René \& AUSTIN WARren i968/1949: Theory of Literature. Third Edition. A Harvest Book 75. New York: Harcourt, Brace \& World, Inc.

YAgOdA, Ben 2004: The Sound on the Page. Style and Voice in Writing. New York: HarperResource. 